Research article

\title{
Ecotourism as a tool for local sustainable development: The case of Burren, Ireland
}

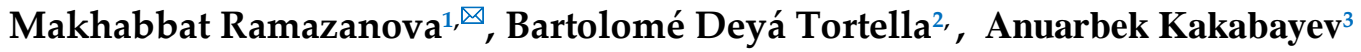 \\ Mihai Bulai ${ }^{4}$
}

1 University of the Balearic Islands, Department of Business Economics, Spain

${ }_{2}^{2}$ University of the Balearic Islands, Department of Business Economics, Spain

${ }^{3}$ Sh. Ualikhanov Kokshetau State University, Faculty of Natural Sciences, Kazakhstan

${ }^{4}$ Alexandru Ioan Cuza University of Iasi, Department of Geography, Romania

\begin{abstract}
Ireland's environment is a key resource in the tourism sector. Burren area in Ireland is becoming an increasingly popular destination, with both international and domestic travellers, where ecotourism is the main activity contributing to the development of the area. Considering this, it is becoming essential to better understand how ecotourism affects the lives of local people from economic and social perspectives, as well as the environment. Thus, this study aims to examine ecotourism development in the Burren and its contribution to local sustainable development. It presents the interview results with the key experts in ecotourism and recommendations towards sustainable development of the region. Furthermore, core indicators of sustainable tourism have been used to assess economic, social and environmental sustainability of the area.
\end{abstract}

Keywords: ecotourism, sustainable development, Burren, Ireland.

\section{Introduction}

Tourism in Ireland is directly dependent on the quality of the environment. It is recognized as a "green" destination with a clean environment, plenty of open space, and a variety of flora and fauna. There are many places with beautiful nature in Ireland. Sustainable tourism development is one of the country's main objectives. In order to be sustainable, tourism should emphasize on the quality of environment as

\footnotetext{
CORRESPONDENCE:

Crt.de Valldemossa, km 7.5, 07122 Palma, Balearic Islands, Spain.

m.ramazanova90@mail.ru (M. R.), tolo.deya@uib.es (B. D. T.), anuarka@mail.ru (A. K.), mihaibulai@yahoo.com (M. B.)
} 
well as its "green" perspective, principles of minimal environmental impact, respect and support for local cultures and traditions, enhancing a formative experience for the tourist that strives for quality over quantity, and guaranteeing its conservation for future generations (UNWTO, 2013). In this context, the role of ecotourism is essential, as a type of tourism aiming at the conservation of natural environment and improvement of well-being of local people (Hill and Gale, 2009).

Our case study area is Burren in County Clare, a county in Ireland, located in the Midwest region and a part of the province of Munster. Ecotourism is considered the main activity in the Burren and plays an important role in the protection of the environment. It involves local people by inviting them to participate in different meetings regarding ecotourism, and it helps to maintain cultural activities in the area. The present work focused on exploring the concept of ecotourism, analysing the development of ecotourism and its main challenges in the Burren, and defining the role of ecotourism as a tool for local sustainable development in the area.

\section{Ecotourism as a growing sector}

Ecotourism is one of the fastest growing sectors of the tourism industry, and research interest in ecotourism has increased over the last several years (Bricker and Kerstetter, 2001; Diamantis 2004; Hill and Gale, 2009). Ecotourism is defined by the International Ecotourism Society as "responsible travel to natural areas, which conserves the environment and improves the welfare of the local people" (TIES, 1990). It is a form of tourism, where participants visit natural areas without damaging the environment, traveling to a destination with undisturbed nature and cultural heritage. However, this type of tourism has both negative and positive impacts on the environment and on society. Thus, it is relevant and useful to incorporate sustainable development into the assessment of ecotourism development. Alexander and Whitehouse (2004) consider that if ecotourism is to induce sustainable development, it must be ecologically sustainable, culturally sensitive, and economically viable. They studied three dimensions of successful ecotourism that meet the principles of sustainable development: economic viability, environmental consequences, and social appropriateness.

- Economic viability in ecotourism facilitates the development of other related industries such as hotel business and restaurants that give local residents opportunities to get permanent jobs, promotes consumption and production, and encourages conservation of protected areas.

- Environmental issues of sustainable ecotourism include promoting environmental protection, increasing environmental understanding of people and changing attitudes and behaviours toward protecting and conserving ecological diversity, as 
well as providing environmental education for expanding knowledge in the ecotourism sector.

- Social sustainability of ecotourism, based on the active participation of local people in the development of ecotourism in their area, empower local people and support local administration.

However, it is difficult to achieve the sustainability of all three indicators in ecotourism. Some of the aspects could be of benefit, while others could bring negative effects. Thus, achieving balance of sustainability between these aspects is an essential for ecotourism development (UNWTO, 2013).

\section{Context of the case study}

The case study for this research is the area of the Burren, County Clare, a county in Ireland, located in the Midwest region and a part of the province of Munster. The Burren is one of Europe's most unique landscapes because of its special character, arising from the complex interaction of its geology and physical landscape, natural scenic beauty, wildlife, a wealth of historic and prehistoric monuments, and local culture and activities.

One of the most visited places in the Burren is the Burren National Park, which lies in one of the most spectacular landscapes in Ireland (Burren National Park, 2013). The dominant feature is bare, pale grey limestone in an endless variety of formations. There are great flat limestone pavements in some areas, while in others the land takes shapes of a series of steps. This unique landscape is generally characterized as a prime example of a limestone karst area, with limestone being the genesis of all its unique features. Ecotourism is the main activity in the Burren. The area attracts a big numbers of visitors each year (Central Statistics Office, 2013). As a result, tourism makes a significant contribution to the local economy (BurrenBeo Trust, 2012).

\section{Methodology}

In order to gather data and to answer the objectives of this study, the interviews with key experts in ecotourism in the Burren were undertaken in April 2013. The key experts in ecotourism play an important role in this research, as they represent the biggest organizations that ensure the protection of the natural resources and the development of ecotourism in the Burren: Burrenbeo Trust, Burren Centre, Burren National Park, Burren and Cliffs of Moher Geopark, Ecotourism Ireland, and Failte Ireland. The main objective of the interviews was defining development of ecotourism products in the Burren and based on it, to identify the role of ecotourism as a tool for local sustainable development. 
The data gathered from the interviews were analysed by using a process of meaning condensation as described by Kvale (1996). Meaning condensation "entails an abridgement of the meaning expressed by the interviewees into shorter formulation" (Kvale, 1996, p.192). This approach follows five key steps, which include:

- Reading the whole interview through to get the sense of the whole;

- Determining the natural units of meaning as expressed by the subject/respondent;

- Stating, as simply as possible, the theme that dominates the natural meaning units as the researcher understands it, but read without prejudice;

- Interrogating the meaning units in terms of the specific purpose of the study;

- Condensing the expressed meanings into more and more essential meaning of the subject of study (Yin, 1994).

\section{Analysis and discussion of the results}

\subsection{Ecotourism development in the Burren}

Ecotourism is a relatively new concept and the existence of various definitions of it is not surprising. The key territorial players which we took into consideration in our research defined ecotourism as a type of tourism that directly related to the environment. As some of the experts noted, it could be confusing for local people to distinguish between ecotourism and nature-based tourism, as nature-based tourism relates to the environment as well. Local people and decision-makers can involve in the implementation of different ecotourism-related goals only it they understand the concept. Thus, the most important thing for ecotourism providers is first to define the concept of ecotourism. However, some of the interviewers believe that there is not a big difference between ecotourism and nature-based tourism, with the only real difference being that nature-based tourism concerns only the environment, while ecotourism is more about benefits to local people as well. They believed that there is no need to distinguish between these two concepts, and asserted that the most important thing is to work on the development of ecotourism in a sustainable way.

When respondents were asked how they define ecotourism at their respective organizations, most of the experts answered that they use the definition of the International Ecotourism Society, which states that 'ecotourism is responsible travel to natural areas which preserves the environment and improves the welfare of the local people' (TIES, 1990). However, the Burrenbeo Trust, a provider of informational and educational materials, defined ecotourism from their perspective, which was that of organizing different events for visitors, ecotourism providers, and interested people (Burrenbeo Trust, 2012). 
Regarding the economic, social and environmental benefits of ecotourism, the respondents considered that ecotourism is one of the main economic activities in the region. Thus, in their perception, tourism brings an important contribution to the local economy and gives opportunities to local people and to guided working companies to get profit from businesses.

As for the environmental benefit, respondents believe that ecotourism is a significant element of environmental protection. Ecotourism is by definition a lowimpact type of tourism that provides environmental benefits. However, ecotourism's impact can also pose a serious threat to the environment. The experts highlight the risks of ecotourism for the environment, deriving from mass tourism, poor visitor management in the area etc. The Burren, Cliffs of Moher Geopark, and Ecotourism Ireland all try to reduce the risks and keep developing ecotourism in a sustainable way (Ecotourism Ireland, 2013). In this case, the measurement and monitoring of sustainability is important.

Regarding the social benefits, ecotourism develops the community by attracting people to it. The co-operative approach gives local stakeholders a sense of place. People who were never involved in ecotourism are able to learn about it, which has very important social benefits.

The role of education is very important in ecotourism development, as these experts mentioned. Ecotourism also has a role in conservation and environment management through expanding different programmes, such as Burren Connect Geopark, which looks at the impact of tourism in the Burren area through working with conservation volunteers and involving tourists and visitors to conserve the environment and to become volunteers. Indeed, it is very important to work with stakeholders, who are really interested in the development of the area. The Burren Centre and other organizations involve local people in the process of decisionmaking through annual meet-and-greets with stakeholders, and work with community groups and advisers through various programmes in the area (Burren Centre, 2009).

\subsection{Does ecotourism contribute to local sustainable development in the Burren?}

The purpose of this section is to test a number of key indicators of sustainable tourism by using findings from the research in the Burren. The identification and selection of core indicators are associated with sustainability-related objectives (Tsaur et al., 2006; TSG, 2007). Below, economic, social and environmental objectives are evaluated by using indicators of sustainable tourism.

\subsubsection{Economic sustainability of ecotourism}


Part of the economic benefit is the generation of income for conservation and the management of national parks and other public land. By using core indicators of sustainable tourism, we assess the data taken from the research as follows:

Tourism volume and value indicator is a critical tool to assess economic sustainability of the area by using the number of tourist overnights per month and daily expenditure per tourist (EU, 2013). According to the data of the Ecotourism Network (2013), the most active months for tourism are June, July, and August. The number of tourists during these months varies from 1000 to 2000 and average tourist expenditure is 80-140 euros per day per person.

Tourism Enterprises Performance affects the sustainability of the destination. Tourist length of stay (measured in nights) is a very important indicator for accommodation providers in the area (EU, 2013). The majority of the visitors take a one-day tour. Some tourists stay between 2 and 7 days in bed and breakfasts, hotels, and hostels.

Quantity and Quality of Employment helps define the role of ecotourism in providing job opportunities directly to local people (EU, 2013). According to the panel of experts surveyed, ecotourism provides new employment opportunities for local people in food industry, accommodation, transportation services, and as local guides. The managing ranger of the Burren National Park believes that ecotourism provides new employment opportunities and businesses to local people from the Ecotourism Network. There are huge benefits to the members of the Ecotourism Network, including the provision of a networking forum, a conservation and advocacy forum, sustainable tourism training and networking programmes, destination marketing, and promotion strategies.

Tourism Supply Chain. Tourism enterprises work with local producers and suppliers and are beneficial to the area by taking steps to develop local, sustainable, and fair trade goods and services. The agriculture and fishing sectors are particularly well-positioned to benefit from tourism (EU, 2013). Also it should be noted that ecotourism development in the Burren has promoted the productive use of land, and has increased farmers' income. The manager of Burren and Cliffs of Moher Geopark believes that the idea of ecotourism is to support and help the economy by using environmentally sustainable methods without damaging other economic activities such as farming and fishing, and even conversely to encourage other economic activities in the area. According to members of the Ecotourism Network, they currently offer many ecotourism-related products in the area. Many of them that do not offer these products are planning to develop the trade of goods and services in the future that will bring more chances to generate income for local people. However, there are several concerns in the area regarding the economic aspect of sustainability. According to members of the Ecotourism Network, the quality of local facilities and 
infrastructure needs to be improved. During an interview, the coordinator of the Burrenbeo trust reported that the main roads are confusing for tourists and discourage them from taking full advantage of the area. Another concern is that the high seasonality of ecotourism is not ideal or sustainable for local people since they can only profit in the summer.

\subsubsection{Environmental sustainability of ecotourism in the Burren}

The environment is one of the main aspects of ecotourism. Using environmental impact indicators help to focus on those elements that are critical to the sustainability of the natural environment of the area.

Reducing Transportation Impact. Use of transportation by tourists to and from the destination brings greenhouse gas emissions and local air pollution. Tracking visitor distance travelled and the specific mode of transport helps increase awareness and encourage improvements in the use of environmental-friendly transportation for tourism (EU, 2013). According to the data obtained from the tourists, most of them use a day tour bus or cars from Dublin to drive to the Burren area.

Landscape and Biodiversity Protection. Protected areas are essential to the destination's tourism product. In order to preserve natural areas, maintaining a high level of biodiversity is important, as it gives an attractive image of the destination. The experts in ecotourism also highlight the role of landscape in the Burren. One of the main objectives of tourists who visit the area is seeing the beautiful landscape in the Burren (EU, 2013).

\subsubsection{Social sustainability of ecotourism in the Burren}

Social indicators are used to define the effects of tourism on the residents and on the cultural heritage in the destination. These analyses will be essential in developing recommendations as well.

Community/Social impact. Visitor satisfaction is a key indicator of the social impact of tourism on a community. Visitors were asked about their satisfaction level with the area. Most of them were satisfied with their visit to the Burren, however, there were some dislikes that indicated areas for improvement, such as the area's infrastructure. This was also mentioned by the tourism product providers (EU, 2013).

Protecting and Enhancing Cultural Heritage, Local Identity, and Assets. Cultural identity is important worldwide. For example, if heritage buildings are destroyed or replaced with modern structures, the character of the destination changes. This is why it is very important to preserve and protect such structures so that they may be maintained for the next generation (EU, 2013). There are many organizations in this area that work on protecting the Burren's cultural heritage. However, the policy for such protection should be developed within the local organizations. 


\section{Conclusions}

Research showed that ecotourism development in the Burren is closely combined with the development of the whole region and has a great potential to be a tool for local sustainable development. The role of the ecotourism organizations, groups, and communities are essential for this. However, as described above, there are some challenges and barriers to ecotourism development that the experts and ecotourism product providers outlined during the research. The Burren Connect project and the Ecotourism Network strive on developing ecotourism in the area by taking into account the opinions of ecotourists as key players in the area (Burren Connect project, 2008).

In order to achieve sustainability of ecotourism in the Burren, involvement of local people is essential. Thus, ecotourism organizations should work with the local community, and people should be involved in their community and learn from their community. The educational aspect is also important in ecotourism. There should be efforts to educate people to use and learn from the environment. Certainly, it would be necessary to provide a very well-balanced education programme, to provide information to visitors, and all stakeholders. Tourism providers should work together, as networking is important. Moreover, ecotourism organizations should learn from other international practices and work on applying them in the Burren.

\section{Acknowledgements}

The authors would like to thank to the members of the Burrenbeo Trust, Burren Centre, Burren National Park, Burren and Cliffs of Moher Geopark, Ecotourism Ireland, and Failte Ireland for their participation in the interviews and sharing their opinions and recommendations on ecotourism development in the Burren.

\section{References}

ALEXANDER, S., WHITEHOUSE, J. (2004). Challenges for balancing conservation and development through ecotourism: insights and implications from two Belizean case studies, WIT Press,

BrICKER, K., KeRSTETTER, D. (2001). Ecotourists and Ecotourism: Benefit Segmentation and Experience Evaluation, West Virginia University, 1-5.

Burren Beo TRust (2013). A Quick Guide to the Archaeology, geology, fauna, flowers, habitats of the Burren, Main street, Kinvara, Co,Galway, Ireland.

Central Statistics Office (2013). Official Website. [online] Available at: www.cso.ie [Accessed 20 Mar. 2013].

DiAMANTIS, D. (2004). Ecotourism: management and assessment, Thomson, London.

EUROPEAN UNION (2013). European Tourism Indicator System TOOLKIT For Sustainable Destinations, DG Enterprise and Industry, EU. 
Hill, J., Gale T. (2009). Ecotourism and Environmental Sustainability: Principles and Practices, Farnham, Burlington, VT: Ashgate, England.

HONEY, M. (1999). Ecotourism and sustainable development: who owns paradise? Island Press, Washington.

KVALE, S. (2007). Doing interviews, SAGE Publications, London.

TOURISM SUSTAINABILITY GROUP, TSG (2007). Action for more Sustainable European tourism, European Commission.

TSAUR, S., LIN, Y., LIN, J. (2006). Evaluating ecotourism sustainability from the integrated perspective of recourse, community and tourism, Tourism Management, 27, 640-653.

YIN, R. (1994). Case study research: Design and Methods, $3^{\text {rd }}$ ed., SAGE Publications International Educational and Professional Publisher, London

ECOTOURISM IRELAND (2013). Official Website. [online] Available at: http://www.ecotourismireland.ie/ [Accessed 25 Mar. 2013].

FAILTE IRELAND (2013). Official Website. [online] Available at: http://www.failteireland.ie/ [Accessed 24 Mar. 2013].

THE INTERNATIONAL ECOTOURISM SOCIETY (TIES, 1990). Official Website. [online] Available at: http://www.ecotourism.org/what-is-ecotourism [Accessed 15 Mar. 2013].

The BurRenBeO TRUST (2012). Official Website. [online] Available at: http://www.burrenbeo.com/ [Accessed 15 Dec. 2012].

THE Burren CENTRE (2009). Official Website. [online] Available at: http://www.theburrencentre.ie/ [Accessed 15 Dec. 2012].

The Burren Connect Project (2008). Official Website. [online] Available at: http://www.burrenconnect.ie/geopark/geopark.html [Accessed 10 Dec. 2012].

The Burren NATiOnAL PARK (2013). Official Website. [online] Available at: http://www.burrennationalpark.iel [Accessed 10 Jan. 2013].

The BurRen ECOTOURISM NeTwORK (2013). Burren Ecotourism Network-Constitution our vision Network, 1-8.

United NATIONS WORLD TOURISM ORGANISATION, UNWTO (2013). Sustainable tourism, Available from: http://www.biodiversity.ru/coastlearn/tourism-eng/con tourism.html 
